\title{
Factors Affecting Switching Job from Private University to Public University in Bangladesh
}

\author{
Md. Alamgir Hossan \\ Lecturer, Department of Business Administration, Daffodil International University, Dhaka, Bangladesh
}

\begin{abstract}
This study aims to investigate the factors that affect prospective employees' Switching intention form private university to Public University in Bangladesh. The paper also examines relationships among the influential factors and switching behavior. The data of the study have been taken total forty-eight (48) attributes into consideration in designing questionnaire for the study. A questionnaire survey method is used with 240 employees and response rate of 90 percent. Initially an exploratory factor analysis is directed using SPSS (version 21).The results indicated that nine factors where employee satisfaction, pay and promotion, job safety and security, Training and development, Employee empowerment, Future Benefits and Switching Behavior are considered as most influential factors and Job security and safety also influential factor for job performance and employee satisfaction. Comparatively Job performance and working condition have less impact on switching decision. Factors Future benefits pay and promotion and training and development have significant relationship with employee satisfaction except the Working condition issues and Switching behavior. The study deals with the focus on a geographic section of the Bangladeshi public and private university employees. This study sets the authority of Privet University and Government can use the findings to better understand, and satisfy the employee to keep in private university for smooth operation of Private University. Therefore, the findings of the study will help to develop the successful private university management policy and strategies.
\end{abstract}

Keywords: Switching Behavior, Employee Satisfaction, Job performance, Private University, Future benefits and job security.

\section{Introduction}

Job Satisfaction is the positive feelings regarding one's job. Job insecurity reduces the organizational commitment and job performance (Masood, Ain, Aslam \& Rizwan, 2014). For getting job satisfaction, the employee switches their job from one organization to another organization. On the basis of management structure of organizations are divided into two types one is Private another is Public organization. Some employees of private organization switch their job to public organization and some are switching their job from public to private organization. (Hur and Perry, 2016), Stated that, the employee of Public organization enjoyed high job security in $20^{\text {th }}$ century. Job satisfaction in public and private organization is significantly different. Private sector employees job satisfaction dependent upon salary, fringe benefit, efficiency in work, quality of supervision and co-workers' relationship etc. Public sector employees job satisfaction dependent on balancing family life and after retirement benefit (Rashid \& Rashid, 2012). The people of developing country like Bangladesh are tried to get public organization job because of security, future benefits, and empowerment. But the people of developed country like United States of America (USA), Canada are tied to stay them in the public service due to social status and patriotism. The factors that affect the employee switching their job from private university to public university in Bangladesh are mostly on job security, safety, future benefits, and employee empowerment. Privatization is the one of main stream of economic development of a country. After liberation, at the very beginning of 1990, Bangladesh government approved some private organization in different sectors which create a lot of employment for reducing unemployment problem of the country. With the approval of some private organization in Bangladesh, The Government also approved some private university at 1990. At 1992 North South University was established for proving the higher education to the student those who are financially affluent. At present near about 95 private and 40 public universities in Bangladesh. Private university has created huge opportunity of employment in academic and administrative both sides. Maslow in 1954 elucidated Job security is significant for employee job satisfaction and it also hygienic factor of motivation. Wonderful significance of organization mission is highly motivated employees toward job performance. Employees are psychologically motivated about the job security in the public sector (Wright, 2007). In the research, I have tried to find out the significant factors which affect for job switching behavior of employee. If the authority of private university is able to meet these factors (which are creating de-motivation) then employee switching behavior will be reduced. This reduction of switching behavior of employee creates a congenial environment for the smooth function of private university education in Bangladesh. Government should come forward to helping the private university management financially and technically. Only private owners are unable to smooth functioning of the university. If government provides some support to private university, the authority will able to fulfill all needs and motivational factors of employees. I have tried to visualize the real scenario of employee dissatisfaction in a private university. The private university owner and government 
simultaneously can solve this problem of employee dissatisfaction of private university. Turnover is the main obstacles of any smooth functioning of an organization, private university is not out of this concept. (Buchanan B. II, 1976) They also stated that human resource most crucial in the any kind of organization either it is public or private in nature. Skilled human resource tries to keep them in the renowned organization. By nature, public organizations are large in size and frame. So, people are motivated in the public organization. Skillful employees are more committed to the organization. Public organization provide huge relax, autonomy, decision making power, dignity job security, and future benefit which helps employees show their potential in their own way. It is hardly shown in the private organization.

\section{Literature Review:}

Job Satisfaction is the way by which employee think, feel and achieve from their job. Job satisfaction minimizes the employee switching behavior and hiring of fresher's expenses. Job security and employee empowerment have played a significant role for job satisfaction of employees. Equity based pays also influences the employees' job satisfaction and turnover. Job insecurity degrades the organizational commitment and job performance in the modern organization (Masood, Ain, Aslam \& Rizwan, 2014). Employee satisfaction comes from both intrinsic and extrinsic effort of employee. Some factors which influence (working condition, employee empowerment, supervisors support) employee job satisfaction is also called extrinsic motivation. On the other hand, employees are motivated with their work due to employee's passions is called intrinsic motivation (Glor, 2002). Employee's public job satisfaction arises from self-interest. It has a long story that in the public service has the civic power as well as employee empowerment opportunities (Perry, 1996). Job satisfaction in public and private organization is significantly different. Private sector employees job satisfaction dependent upon salary, fringe benefit, efficiency in work, quality supervision and co-workers' relationship. Public sector employees job satisfaction dependent on balancing family life and after retirement benefit (Rashid \& Rashid, 2012). (Perry abs Porter, 1982) Found that there are four motivational techniques in public sectors' employee job satisfaction, these are monetary incentives, Goal setting, Job design and participation. They also suggested that goal clarity and job security also increase the job satisfaction to the employees. (Hur and Perry, 2016), Said that, public employees enjoyed high job security in $20^{\text {th }}$ century. In $21^{\text {st }}$ century public sector job security depends on ideological consideration. Job insecurity is the causes of employee performance and their ability. Maslow in 1954 elucidated Job security is significant for employee job satisfaction and it also hygienic factor of motivation. Wonderful significance of organization mission is highly motivated employees toward job performance. Employees are psychologically motivated about the job security in the public sector (Wright, 2007). Public managers have significantly positive relationship with job satisfaction where private managers have not same as public. Public job position has significant meaning to employee which is not available at private one. Public sector maintains huge bureaucratic system and inefficiency. Job security and fringe benefits are the main motivational factors for switching to public university job (Rainey, 1982). Private sector pays more $25 \%$ than public sector in the United States of America but public sector employees enjoy more power and opportunities to make federal policy. Better monetary benefits are not the factor for job satisfaction in American public service motivation. Decision making power is the prime consideration for the high job satisfaction in the United States public service motivation (Alonso \& Lewis, 2001). In the mid 1960s public service confidence had declined. At that time there is no comparison between public and private service motivation. Bureaucracy is one of the drawbacks for public service motivation. The root of public motivation is human behavior, incentives, organization itself. Intrinsic reward also motivates people for public service. Prestige is the factor that influences and attracts for public sector jobs. Prestige is considered as an incentive for employees. Public and private managers have some motivational differences. Formulation of public policy is another strong zone for public service motivation. Red tape and length of organizational membership have the negative effect on public service motivation but hierarchical authority has a positive impact on relationship. Using different indirect measures, different theory for same position level's employee creates dispute on the employee. They also suggested that organizational culture, red tape, hierarchy reform orientation and length of organizational membership impact on public service motivation. Public service motivation is not only the result of individual socio-historical background but also the organizational environment in which employees find themselves. Loyalty, motivation and commitment that is more effective than monthly incentives. Unnecessary control also creates negative impact on the employee for public service motivation (Moynihan \& Pandey, 2007). 10 percent of manager spent their time for identifying the tactics which applies employee motivation but reality is that managers can identify accurately the picture as to what really motivate their employees. They also addressed that the inability of timely providing motivational determinates create the complexity in compensation and incentive programs. Earlier the managers are lists 10 motivational factors which actually motivates employees; these are, (1) Interesting work. (2) Full application of work done. (3) Feeling of being in on things. (4) Job security. (5) Good wages. (6) Promotion and growth of the organization. (7) Good working conditions. (8) Personal loyalty to employees. (9) Tactful discipline. (10) Sympathetic help with personal problems. After one of survey it had been found that there is 
disparity between managers' belief and reality. The motivation of public and private sector is mixed. Public sector motivators are job security and stability, teamwork and worthwhile service to society, monetary rewards, prestige, teamwork and the desire for challenging and autonomy etc. Private sector motivators are status, opportunities to advance, autonomy and high pay etc. while being unconcerned with worthwhile contributions to society and job security (Jurkiewicz, Massey \& Brown, 1998). Public sector occupations are motivated by career needs which are substantially distinct from those associated with the private sector. They also suggested that there are three components interrelated with the public motivation, these are individual choice, Public interest and loyalty and patriotism and altruism. Patriotism of benevolence should be paramount for public administrator which is the opposite of egoistic advancement of current in the private sector. Public sector employees are getting more priority in contest of special degree program, training center, university department, government research design, codes of ethics and thriving professional associations. They further said that there is no difference between bureaucratic ethos in public and private value system. They also proposed that with the quotation of former US Supreme Court justice Hugo Black argued to have said "I am not being able to define pornography but I can tell it when I see it." Defining public sector motivation is similar of the quotation of Hugo Black (Gabris\& Simo, 1995). Public employees are less extrinsically motivated than that of private sector employees. On the other hand, private sector employees are less intrinsically motivated than that of public sector employees. Most of the research showed that the private sector employees are highly paid than that of public sector employees (Buelens\&Broeck 2007). Public organizations have more complexity and ambiguity. In case of formalities there are no significant differences between public and private organization's management. Government organizations face long red tape and rules that private organizations have not. Private organizations are inherently superior in efficiency and effectiveness. How many areas are similar in the management of private and public organization? It is more different. Public organization's managers have less capacity to provide reward to their employee than private organization. The perception of rule enforcing between public and private organization's manager is similar. The formalities of Canadian public university and private university are different, it also shown in the USA private and public schools. Public organization's managers take more time to purchase decision of any official equipment than private organization (Rainey \& Bozeman, 2000). Public and Private organizations are slightly differ in organizational incentive structures, goals and individual roles as they are perceived by their organization. Public organizations are influenced by the external forces like, legislative bodies, other units of the executive branches and courts imposed standards and procedures. As private organization is financed by private ownership, the authority is lower of public in goal and decision making. Public organization maintains the high formalities than private organization. Civil service rules are weakening the relationship between individual performance and certain extrinsic rewards. There is complex and rigid procedure for hiring, firing, promotions and pay. Observation shows that there is low morale and motivation in public organization. Public ownership goals are complicated where private is more easy. As the goal of public organization is vague, the employees are not able to meet the organizations' rules easily (Rainey. 1983). The employees of public organizations are enjoying high extrinsic benefits where the employees of private organizations are enjoying intrinsic benefits. Pay for performance is the main stream of private service motivation which is totally absent in public sectors. He also suggested that the public sector employees are less emphasis on job security than do private sectors. Private sector employees are more focusing on extrinsic motivation with high pay, status, prestige and promotion (Houston, 2000). The logic of service and the logic of profit are negatively related with each other which is exists in private organization. Public employees are perceived nature of a relationship which affects individual motivation. Public organizations are facing participation constraints in decision making. If public organization offers lower wage and salaries, the applicants are not motivated to apply in public organization. Primitive basic model is the cause of employee dissatisfaction in the public sectors. Employees come to the public organization voluntarily for serving common people of the state (Frabcois, 2000). Public organizations are more bureaucratic and managers are materialistic and have weaker organizational commitment than private sectors counterparts. Sometimes public managers learn some management techniques from private managers. Similarities and differences between private and public organization are the issue of debate nowadays. In the public organization the owners are indirectly influenced on monetary matters where private organization owner directly influenced (Boyne, 2002). Public service motivation depends on three things these are institutional and environmental factors. The work itself and individual needs and motives. People try to work as a public servant due to seeking the membership of a public organization. The employee of public organization gets more value from private counterparts, this social valuation directly impact on job satisfaction. The job satisfaction and intention of public employee is to stay in their job when employee felt their work is meaningful and good for society (Perry \& Rainey, 1988). Difference between public and private organization are mostly on, environments, constraints, incentives, and culture. Public and private vary along at least three dimensions such as, interest, access and agency. There is philosophical difference between public and private organization (Rainey H. G. 1989). Virtually, there is no difference between public and private tasks. Public agency includes in efficiency and rigidity. Public management is more haphazard than private 
counterparts. In the public organization political influence is high which is comparatively low in private organization. There are huge formalities in public management system but it is low formalities in the private organization (Rainey, 1979). There is a deleterious impact of civil service system on incentives in government organization. It is often argued that complaints by public administrators about inability to fire, or to reward for excellence with promotion or with higher pay. Private organization can reform the new motivational and incentive proposal for employee but it is quite tough in the public organization (Rainey H. G. and et.el, 1976). Public and Private Organization faces similar types of challenges and problems and solve accordingly. They also found that there are different environmental factors influences different in Public and Private University (Wittmer D. 1991). Attracting the public employee is more difficult than private employees due to the size of organization. Bureaucratic attitude is normal phenomenon in the public organization but it not found in private organization. Recruitment and selection procedure is not similar in both public and private sector organization that's why decision making and leadership style also different. Job security is high in public sector that's why service ethics is low. In the private sector job security is comparatively low that's why the employee maintains all rules and regulation of organization (Buchanan B. II, 1976). They also stated that human resource is the most crucial in the any kind of organization either it is public or private in nature. Resourceful employee tries to keep them in the large size organization. By nature public organizations are large in area and size. So, people are motivated in the public organization. Skillful employees are more committed to the organization. Public organization provide huge relax, autonomy, decision making power, dignity job security, and future benefit which helps employees show their potential in their own way. It is hardly shown in the private organization.

\section{Conceptual Framework:}

Based on a review of the literature, this study has developed a framework linking Pay and Promotion, Training and Development, Working Condition, Employee Empowerment, Job Security and Safety, Job Performance, Employee Satisfaction and Switching Behavior. The figure indicates the hypothesized model for Employee Satisfaction and examines the relationship between the attributes of employee switching behavior.

Generally, Behavior describes a response of an individual or group to an action, environment, Person, or stimulus (Oxford Dictionary). Behavior is essentially observable physical activity: a pigeon pecks a disk, a woman says "hello," a student raises his hand, and so forth (Raymond M. Bergner, 2011). Behavior put people into a frame of mind of liking or disliking things of moving toward or away from them. Here switching attitude indicates that the tendencies of Employees to favor or disfavor the organization based on evaluations of the attributes of an organizational opportunity.

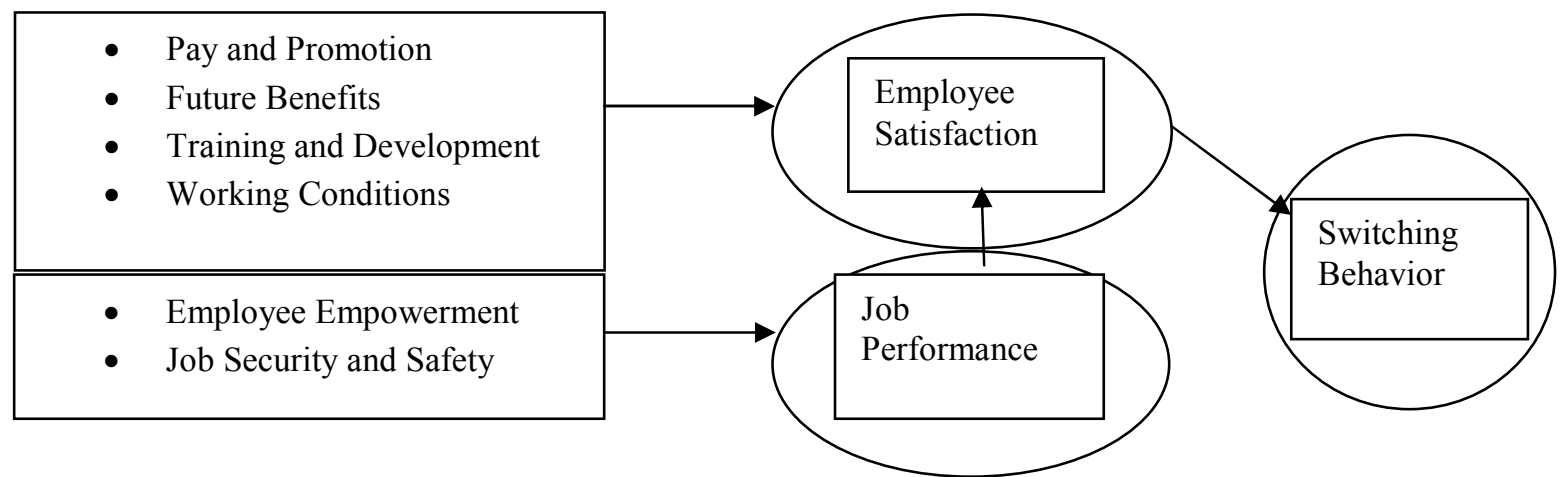

Figure 1: Hypothesized Model of Employee Switching Behavior.

H1: Pay and Promotion has the positive effect on Employee Satisfaction.

$\mathrm{H} 2$ : Future Benefits create employee satisfaction in a positive way.

H3: Training and Development increases the Employee satisfaction in the organization in a positive manner.

H4: Working Condition attracts the employee satisfaction positively.

H5: Employee Empowerment increases the employee Performance.

H6: Job Security and Safety extends the Job Performance.

H7: Job satisfaction has positive linked on Employee better job Performance.

H8: Finally, Employee Satisfaction has strong impact on Switching Behavior.

\section{Objectives of the Study:}

- To identify the factors that affect employee switching attitudes from Private university to Public University in Bangladesh

- To identify the relationships among the factors of employee satisfaction, Job Performance and Switching Behavior. 


\section{Research Methodology:}

5.1. Sampling Design: For the study, all the employee of private and public university either academic or administrative position in Bangladesh were considered as target population. Sample frame included employees who are serving different public and private university at Dhaka city and outside of Dhaka city in Bangladesh. For this study, the study used two types of sampling techniques namely, simple random sampling and convenient sampling. Initially, 220 questionnaires were distributed to the respondents for their responses but a total 203 usable questionnaires were collected.

5.2. Data Collection and Analysis: Through literature review and field survey with open ended questionnaire the study has found more than 74 attributes that influenced the employee in the organization for their satisfaction. Then, the relationships of similarities and dissimilarities $(+,-)$ among the variables were portrayed based on empirical research. Then respondents' comment and ideas were incorporated into the design of the final questionnaire. After the several round revisions a total number of 48 attributes were considered for designing final questionnaire. To test the reliability of the questionnaire a pilot survey was used. In pilot test 50 questionnaires were approached and collected from the private and public university academic and administrative employees. To test the internal consistency of each of the attributes, dimensions, and items of the attitudes this study is applied the Cronbach's Alpha reliability analysis. The results showed the Cronbach Alpha coefficients for the overall questionnaire was 0.902 , indicating that the reliability of the questionnaire was quite high. This study collected data through a survey conducted in the major areas of Bangladesh using a detailed structured self-administered questionnaire. The respondents were asked about different attributes those are usually considered for employee switching behavior by using 7 point Likert scale. For the data collection process, I have designed a questionnaire in Google form and personally visit with different academic and administrative employees of Daffodil International University. Moreover, one of my friend, Lecturer, Department of Accounting and Information Systems, Comilla University Help me to collect data from a few academic personnel of Comilla University. All the data were analyzed in Statistical Package for Social Science (SPSS) and MS Excel and finally report is produced based on the analyzed data.

\section{Findings and Discussion:}

6.1. Scale Reliability: To test the internal consistency of each of the attributes, dimensions, and items of the attitudes the study applied the Cronbach's Alpha reliability analysis. In this study, a total of 48 items (43 items from the influential factors and 5 items from the switching Behavior) have been considered. In scale reliability analysis, the study has found that the value of Alpha is 0.902 which is highly reliable (Nunnaally, 1978).

\section{Reliability Statistics}

\begin{tabular}{|r|r|r|}
\hline \multicolumn{1}{|c|}{ Cronbach's Alpha } & Cronbach's Alpha Based on Standardized Items & N of Items \\
\hline .902 & .928 & 48 \\
\hline
\end{tabular}

\subsection{Exploratory Factor Analysis:}

In order to identify the influential factors and attributes of employee switching behavior the study has conducted an exploratory factor analysis. Initially the study has considered 74 variables. Finally, the study has taken 48 variables.

Kaiser-Meyer-Olkin (KMO) measure of sample adequacy test was applied on influential factors to test whether the sample was adequate to consider the data was normally distributed or not. The KMO value was $\mathbf{0 . 8 4}$ indicating that the sample size was adequate to consider the data normally distributed as the KMO values above 0.5 are considered to indicate normality of data.

Bartlett's Test of Sphericity has been used to test the null hypotheses that the variables in the study are not correlated. The Chi-Square test value was 3220.931, which was significant at $\mathbf{0 \%}$ level of significance. The test indicated that variables in the study were correlated and rejected the null hypothesis (The population correlation matrix is an identity matrix). Therefore, the data were suitable for factor analysis.

KMO and Bartlett's Test

Kaiser-Meyer-Olkin Measure of Sampling Adequacy.

Bartlett's Test of Sphericity

Approx. Chi-Square

df

3220.931

Sig.

\subsection{Influential Factors:}

The principal component analysis was used as the extraction method associated with the rotation method of Varimax with Kaiser Normalization. This study has examined communalities of each attribute accounted for the research. Initially 74 items were approached for this test. This study did not find absolute communalities score 
for all items. Hence, 26 items that scored less than 0.5 have been dropped from the data set. Since data have been collected from field survey, authors have considered current score level for 48 items included in 9 factors. Therefore 9 factors have been extracted on the basis of Eigen values and variance explained by them. The factors were named based on communality of all the items that converged on that factor. Finally this study has identified eight factors namely Pay and Promotion, Future Benefits, Training and Development, Working Condition, Employee Empowerment, Job security and Safety, Employee Satisfaction and Employee Performance that robustly influence the employee preferences in switching job form private university to public university in Bangladesh. Information about the factors is summarized below:

Pay and Promotion: Pay and promotion is the main attraction of employee job satisfaction. Competitive pay structure and timely promotion increases employee satisfaction, on the other hand poor payment structure and late promotion enhance employee switching intention. The most significant attribute of this factor is the employee being rewarded for their quality of service which score is (.722). The mean value of this factor is 4.40 that indicating its significance.

Future Benefits: Future benefits indicate the financial benefits after retirement of employee from the organization. When employee getting retired from the university he/she feel insecurity financially. If organization unable to ensure for the future benefit, the employees switching behavior will be positively increased. This factor strongly affected on employee switching intention. This factor high coefficient is availability of retirement benefits (.869). Four (4) attributes has considered for this factor and all are highly correlated with each other. The mean value of this factor is 3.63 which showing its importance.

Training and Development: Training is the process of teaching new employees the basic skills they need to perform their jobs (Gary Desslar, Human Resource Management, $10^{\text {th }}$ Edition). Development is any attempt to improve current or future management performance by imparting knowledge, changing attitude or increasing skills (Gary Desslar, Human Resource Management, $10^{\text {th }}$ Edition). This factor also has impact on job satisfaction. Absence of training and development program in the organization creates employee turnover intention. This factor consists of five (5) attributes, all are highly relating with others. The most influential attribute is frequently arrangement of training program in the university. The factor mean value is 4.60 that prove its relatedness.

Working Condition: Working condition means the physical arrangement of the organization for the work. Employee always expects congenial working environment. When employee understands the unfriendly environment the switching intention takes place. This factor indicates six (6) attributes. The most influential attribute is seniors are supportive for the employee which significance score is (.763). The mean value of this factor is 4.96 .

Employee Empowerment: Employee empowerment is the getting the authority and discretion for taking decision in the critical situation of the organization. This factor enhances employee job performance as well as employee satisfaction. The poor employee empowerment turns the employee to switch one organization to another. This factor is formulated with five (5) attributes. All are highly related one with another and the mean value of this factor is (4.88). The most significant attribute is the daily problems solving capability (.841).

Job Security and Safety: Job security is the getting certainty for doing job in the organization and the employees will not loss their job suddenly. The attributes of this factor are Six (6). The mean value is 4.03 that indicate the factor's relationship. The most significant attribute in this factor is I have no fear for losing my job which score is (.856).

Employee Satisfaction: Employee satisfaction is positive feelings toward one's job. This satisfaction depends on different factors. The absence of these factors arises employee dissatisfaction which ultimately gear up the employee for switch the job to other organization. This factor constitutes with Six (6) distinguished attributes and their men value is 4.33. The major attributes of this factor is high coefficient for meeting employees' maximum expectation (7.59) and organization's creative program (7.37). Six attributes have considered this factor which is highly correlated.

Job Performance: Job performance is the job-related activities expected of a worker and how well those activities were executed (Oxford Dictionary). Job performance has strong influence on Employee satisfaction. The negative outcome of this factor encourages the employee for switching the job to another organization. This factor includes Four (4) attributes which mean value is (5.6). The most significant attributes' value is employee's performance is better than that of other employees with similar qualifications (.902). 
6.4. Relationships among the influential factors and switching of Employees from Private University to Public University in Bangladesh:

\begin{tabular}{|c|c|c|c|c|c|c|c|c|}
\hline \multirow[t]{2}{*}{ Hypotheses } & \multirow[t]{2}{*}{ Dependent } & \multirow[t]{2}{*}{ Independent } & \multicolumn{2}{|c|}{$\begin{array}{l}\text { Unstd. } \\
\text { Coefficients }\end{array}$} & \multirow{2}{*}{$\begin{array}{l}\text { Std. } \\
\text { Coefficients } \\
\text { Beta }\end{array}$} & \multirow[t]{2}{*}{$\mathrm{T}$} & \multirow[t]{2}{*}{ Sig. } & \multirow[t]{2}{*}{ Results } \\
\hline & & & $\mathrm{B}$ & $\begin{array}{l}\text { Std. } \\
\text { Error }\end{array}$ & & & & \\
\hline H1 & $\begin{array}{l}\text { Employee } \\
\text { Satisfaction }\end{array}$ & $\begin{array}{ll}\text { Pay and } \\
\text { Promotion }\end{array}$ & .373 & .089 & .374 & 4.206 & .000 & Accepted \\
\hline $\mathrm{H} 2$ & $\begin{array}{l}\text { Employee } \\
\text { Satisfaction }\end{array}$ & Future Benefit & .176 & .058 & .227 & 3.064 & .003 & Accepted \\
\hline $\mathrm{H} 3$ & $\begin{array}{l}\text { Employee } \\
\text { Satisfaction }\end{array}$ & $\begin{array}{l}\text { Training and } \\
\text { Development }\end{array}$ & .238 & .081 & .262 & 2.941 & .004 & Accepted \\
\hline $\mathrm{H} 4$ & $\begin{array}{l}\text { Employee } \\
\text { Satisfaction }\end{array}$ & $\begin{array}{l}\text { Working } \\
\text { Condition }\end{array}$ & .098 & .090 & .096 & 1.090 & .279 & Rejected \\
\hline H5 & Job Performance & $\begin{array}{l}\text { Employee } \\
\text { Empowerment }\end{array}$ & .327 & .079 & .401 & 4.142 & .000 & Accepted \\
\hline H6 & Job Performance & $\begin{array}{l}\text { Job Safety and } \\
\text { Security }\end{array}$ & .151 & .070 & .209 & 2.137 & .035 & Accepted \\
\hline $\mathrm{H} 7$ & Job Performance & $\begin{array}{l}\text { Employee } \\
\text { Satisfaction }\end{array}$ & .253 & .094 & .264 & 2.705 & .008 & Accepted \\
\hline H8 & $\begin{array}{l}\text { Switching } \\
\text { Behavior }\end{array}$ & $\begin{array}{l}\text { Employee } \\
\text { Satisfaction }\end{array}$ & -.672 & .115 & -.505 & -5.815 & .000 & Accepted \\
\hline
\end{tabular}

\section{Conclusion and Implications:}

Job Satisfaction is the precondition for keeping resourceful employee in the organization. Every successful human resource manager tries to satisfy their employees but it is quite difficult in real situation. Most of the organizations are failed to satisfy their employee due to different management inefficiencies, As a result the organization faces lack of resourceful employee. When employees are dissatisfied, they try leaving the organization. For keeping Employee satisfaction in the organization is very tough job but a dynamic manager must do it. Employees are feeling insecurity of their job in the organization. So, organization should ensure job security as employees are not feeling threat of job insecurity. The main cause of switching job from private university to public university in Bangladesh is lack of job security and future benefit. When the authority is able to ensure job security and safety, and future benefit then switching behavior will be negatively approached. The other factor also affects the switching behavior of employees is delegation of authority (Employee Empowerment). The author should delegate the authority to the employees then employee switching behavior may be reduced.

For sustaining the employee service in the private organization all dynamic and modern manager should apply labor law which is totally absent in the Human Resource Management in Bangladesh especially in private university. Government should come forward to take some measures for the development of private university teaching in Bangladesh beside private owners. Proper regulation should be formulated for the private university teachers and this regulation should be implemented for reducing switching intention of employee form private university to public university. My research has revealed eight influential factors of employee switching from private university to public university in Bangladesh. When employees think about their long-term career then they considered about future benefits and job security and safety and empowerment. Due to absence of these opportunities in the private university the employees are attracted to public university job in Bangladesh. Employee empowerment (Mean Value: 4.88) get the highest priority in case of switching intention. This factor ultimately influences job performance of the employee. Private university board of trustees should aware about these factors for sustaining their resourceful employee for long term benefit of the university. Sometimes private university authority takes some decision which is not appropriate with teaching. To ensure quality education the private university authority should avoid this type of decision which is bad for employees as well as university. Besides the aforesaid factors the private university authority should provide on time promotion, ensure future benefits and job security.

\section{Limitation and Further Research:}

The present study is not out of limitations. Some constraints are appended like our sample size was limited. Convenience sampling technique was used to collect data which is not enough to serve the purpose. The employees were too busy to provide researchers much time for responding to the questionnaires. The authors did not have the opportunity to compare the employees' preferences and attitude among the various universities. Employee switching behavior is big concept; I have studied only about private and Public University in Bangladesh. So further research is encouraged to consider more samples as well as compare behavior and attitudes of employees in private and public organization in all sectors. In this study authors have identified factors and attribute that influence employee to switch from private university to public university in Bangladesh. 
The authors have the plan to measure employees' switching behavior on the concerned factors and attributes of total private and public sectors across the country. Therefore, further research will be conducted on the switching behavior of employee in private and public all sectors in Bangladesh.

\section{References:}

1. Masood, A., Ain, Q.U., Aslam, R., \& Rizwan, M. (2014). Factors Affecting Employee Satisfaction of the Public and Private Sector Organizations of Pakistan. International Journal of Human Resource Studies, 4(2), 97-121.

2. Glor.E.D. (2002). Key factors influencing innovation in Government. The public sector innovation journal. $7(2), 1-19$.

3. Rashid, S. \& Rashid. U. (2012). Work motivation differences between public and private sector. American International Journal of social science, 1(2), 24-33.

4. Perry, J. L. (1996). Measuring Public Service Motivation: An Assessment of construct reliability and validity. The Journal of Public Administration research and theory, Inc. 6(1). 5-22.

5. Hur, H. \& Perry, J.L. (2016). Evidence based change in public job security policy. Public personnel management. 45(3). 264-283.

6. Wright, B.E. (2007). Public service motivation: Does Mission matter? Public Administration Review. January, 54-64.

7. Rainey, H.G. (1982). Reward preferences among public and private managers. American review of public administration. 15(Nob), 288-302.

8. Alonso, P. \& Lewis, G.B. (2001). Public Service Motivation and job Performance. The American Review of Public Administration. 31(4), 363-380.

9. Perry L.J. \& Wise L. R. (1990). The Motivational Bases of Public Service. Public Administration Review. 3(June), 367-373.

10. Jurkiewcz C.L., Massey T. K. \& Brown R. G. (1998). Motivation in Public and Private Organizations: A comparative study. Public Productivity \& Management Review, 21(3), 230-250.

11. Moynihan D. P. \& Pandey S. K. (2007). The Role of Organizations in Fostering Public Service Motivation. Public Administration Review, January, 40-52.

12. Gabris G. T. \& Simo G. (1995). Public sector motivation as an Independent Variable affecting Career Decision. Public Personnel Management, 24(1), 33-51.

13. Buelens M. \&Broeck H. V. D, (2007). An Analysis of differences in work Motivation between Public and Private Sector Organization. Public Administration Review, January, 65-74.

14. Rainey H. G., \& Bozeman B. (2000). Comparing public and private organizations: Empirical Research and the Power of the Priori. Journal of public Administration Research and Theory, 10(2) 447-469.

15. Rainey H. G (1983). Public Agencies and Private Firm: Incentive Structure, Goals and Individual structure. Administration \& Society, 15(2), 207-242.

16. Houston D. J., (2000). Public Service Motivation: A Multivariate Test. Journal of Public Administration Research and Theory, 10(4), 713-727.

17. Francois P., (2000). 'Public Service Motivation' as an argument for Government Provision. Journal of Public Economics, 78(2000), 275-299.

18. Boyne G. A., (2002). Public and Private Management; what's the Difference? Journal of Management Studies, 39(1), 97-122.

19. Perry J. L., Hosdeghen A. \& Wise L.R., (2010). Revising the Motivational Bases of Public Service: Twenty Years of Research and agenda for future. Public Administration Review, September, 681-690.

20. Perry J. L. and Rainey H. G., (1988). The Public- Private Distinction in organization Theory: A critique and Research Strategy. Academy of Management Review, 13(2), 182-201.

21. Rainey H. G., (1989). Public management: Recent Research on the political content and managerial Roles, Structures, and Behaviors. Journal of Management, 15(2), 229-250.

22. Rainey H. G., (1979). Perception of Incentives in Business and Government: Implications for civil Service Reform. Public Administration Review, 39(5), 440-448.

23. Rainey H. G., Backoff R. W., and Levine C. H. (1976). Comparing Public and Private Organization. Public Administration Review, 36(2), 233-244.

24. Wittmer D, (1991). Serving the serving for pay: Reward Preferences among Government, Hybrid sector, and Business Managers. Public Productivity and Management Review, 14(4), 369-383.

25. Bruchanan B. II, (1974). Government Managers, Business Executives, and Organizational Commitment. Public Administration Review, 34(4), 339-347.

26. Mostafa K.andPramanik S.A.K. (2015). Factors Affecting Customers to Buy Apartment in Dhaka City. Daffodil International University Journal of Business and Economics, 9(2), 37-49. 